\title{
既存高速道路のマクロ経済及び人口分布 に対する整備効果に関する研究
}

\author{
上田大貴 $1 \cdot$ 片岡 将 $2 \cdot$ 柳川 篤志 $3 \cdot$ 川端 祐一郎 $4 \cdot$ 藤井 聡 5 \\ 1学生会員 京都大学大学院 工学研究科都市社会工学専攻（干615-8540 京都市西京区京都大学桂4） \\ E-mail: ueda.h@trans.kuciv.kyoto-u.ac.jp \\ 2学生会員 京都大学大学院 工学研究科都市社会工学専攻（广 $615-8540$ 京都市西京区京都大学桂4） \\ E-mail: kataoka.s@trans.kuciv.kyoto-u.ac.jp \\ 3正会員 中央復建コンサルタンツ株式会社（†533-0033 大阪市東淀川区東中島4-11-10） \\ E-mail: yanagawa_a@cfk.co.jp \\ 4正会員 京都大学大学院助教 工学研究科都市社会工学専攻（†615-8540 京都市西京区京都大学桂4) \\ E-mail: kawabata.yuichiro@trans.kuciv.kyoto-u.ac.jp \\ 5 正会員 京都大学大学院教授 工学研究科都市社会工学専攻（一615-8540 京都市西京区京都大学桂4) \\ E-mail: fujii@trans.kuciv.kyoto-u.ac.jp
}

\begin{abstract}
本研究では, 交通インフラ網整備がもたらすマクロ経済への効果及び各地域の人口や経済力分布への影 響を推計するため, 既往研究で提案されているモデルシステム（MasRAC）を用いて, 既に利用されてい る高速道路がもたらしてきた効果の評価を行った。その結果，今日までの我が国における高速道路整備は， 国全体に対しては多大な豊かさをもたらしてきた一方で, 整備によって人口や経済力の地方部から三大都 市圈への集中を促し，より成長した地域と成長が阻害された地域を生み出す，すなわち国土の不均衡のあ 拡大を招くものであった可能性が示唆された。 これらから，地方の高速道路整備をより一層十分に行うこ とで, マクロ経済のさらなる底上げとともに, 地方からの経済力の流出が軽減され, より豊かでバランス のとれた国土が形成され得ると考えられる。
\end{abstract}

Key Words : accessibility, highway, decentralized, population, GRP

\section{1. 本研究の背景と目的}

1980年代以降，我が国において東京一極集中及び地方 の衰退が大きな問題となっている. これを受け 1987 年 に策定された第四次全国総合開発計画（四全総）では，

「多極分散型国土の構築」を基本目標とし，東京圈への 一極集中の是正と地方圈の戦略的，重点的整備による活 性化を目指すことが定められた，道路整備についてはこ の目標に対応して，それ以前の三大都市圈や太平洋側地 域を中心とする高速道路網計画に代わり，地域間の交流 ネットワークを充実させ，高速交通サービスの全国的な 普及を図る $14,000 \mathrm{~km}$ に及゙高規格幹線道路網の形成が定 められた1).

この整備推進により，人口 10 万人以上の都市の連絡 は概ね達成され，三大都市圈間を結ぶ新たな路線の建設 によるリダンダンシー向上が進められる一方で, 地方部, 特に本州以外の 3 島や東北，山陰地域には，未だ多くの
未供用路線（ミッシングリンク）が残されている. 高速道路整備が停滞している一つの要因は, 厳しい財 政制約や公共事業の非効率性の指摘等により，世論やマ スメディアにおいて，交通インフラ整備の必要性を疑問 視する批判的な声が高まったことである2). 政府は歳出 の削減を重視して公共事業の実施には慎重になり, 90 年代半ばには 6\%を超えていた一般政府の総固定資本形 成の対 GDP 比は，2000年代半ば以降は 3\%台にまで低迷 している ${ }^{3}$. 高規格幹線道路網についても，計画の策定 時には 21 世紀初頭に建設を完了寸ることが目標とされ ていたが，実際の整備ペースはその約 7割にとどまって (る4).

高速道路整備の停滞のもう一つの要因として考えられ るのは, 整備効果の過小評価である. 現在我が国では道 路事業の実施判断は, 主に走行時間短縮, 走行経費減少, 交通事故减少の 3 便益の総和をインフラ整備による便益 として計上し，これを整備事業の実施と完成後の維持管 
理に必要とされる費用で除した值（費用便益比，B/C) を用いて，事業の効率性，妥当性を社会・経済的な側面 から評価する費用便益分析である5)。ここでの便益には, 事業実施に伴う公共事業費の投入による雇用創出や経済 の活性化といった効果や, 都市間の近接性の向上や物流 コストの軽減による整備地域周辺への企業立地増加とい った効果は，二重計上の可能性があるため考慮されてい ない. しかしこうした慎重な集計方法によって, 効果が 過小評価されている可能性は否定できないことを，藤井 は指摘している9.

我が国の経済成長力を高め, 多極分散型の国土を形成 するための政策を立案していく上では，交通インフラ整 備によるマクロ経済効果や人口・経済力の地域間分布一 の影響が具体的にどの程度であるのかを評価する適切な 手法が必要となる.

根津・藤井はそうした問題意識に基づき，交通インフ ラの整備によってもたらされる，国内総生産を始めとす るマクロ経済一の効果と, 全国各地域の人口や経済力の 分布に及ぼす効果の双方を総合的に評価できるモデルシ ステム (MasRAC) を構築した7)。このモデルを用いる ことで，将来の交通インフラ整備がもたら寸効果につい て，マクロ・地域の双方を視野に入れた総合的な評価を 行うことが可能となった.

MasRAC は原理的には, インフラ整備とマクロ経済, 地域人口，地域経済の関係に関する過去のデータを用い てそれらの関係を推定し，その推定結果を利用して将来 のインフラ整備効果を予測するものである。これは MasRAC に限らずその他の多くのシミュレーション法に 共通寸ることであるが，過去の効果を正確に把握できな い限り, 将来の効果を適切に予測することも不可能であ る.ところでこのことは，技術的な将来予測に限らず， たとえば公共事業をめぐる世論形成などにおいても同様 のことが言えるのではないだろうか.つまり，過去に整 備が行われ既に利用されている交通インフラが我々の生 活にどれだけ大きな影響を及ぼしているかを理解するこ となしには，将来のインフラ整備への適切な世論形成も 行われ得ないということである.

「既に供用されている交通インフラ」に関し，供用開 始当初からの長期的なデータを用いて，それらが我が国 の経済に与えた総合的な効果を評価するという試みは, これまでのところほとんど行われていない.しかし，過 去の幹線交通網整備の効果を歴史的に展望し，その影響 を定量的に事後評価することは，今後の行われる整備プ ロジェクトの進め方を検討寸る上で多くの示唆を与えう るものであり，また整備に対するコンセンサスを得る重 要な方法の一つであることが指摘されている8,9.9.

そこで本研究では，MasRACを用いて，既に利用され ている高速道路ネットワークの一部あるいは全部が仮に
整備されなかった（存在しなかった）とした場合に，我 が国の経済水準がじれだけ低迷し，また人口や経済力の 分布がどれだけ偏っていたかを定量的に明らかにするこ とを試みる。

高速道路が整備されなかった場合に失われたであろう

「豊かさ」や「国土のバランス」を定量的に把握するこ とを通じて，現に存在する高速道路のもたらしている効 果を改めて認識するとともに, ひいては将来の交通イン フラ整備の適切な推進とそれに向けた合意形成を促すよ うな知見を供することが，本研究の目的である.

\section{2. 既往研究と本研究の位置づけ}

交通インフラ整備による効果は, フロー効果とストッ ク効果の二つに大別できる ${ }^{10)}$. フロー効果は, 公共事業 費が投入されることで生産活動や雇用が創出され，所得 や消費が拡大寸る効果を指しており，事業実施とともに 生じる短期的な効果であるといえる.このフロー効果に は，事業費が関係者の所得となるだけでなく，こうして 支払われた所得が新たな支出を生み出寸乗数効果も含ま れる.

一方ストック効果は, 鉄道や道路の発達により, 所要 時間の短縮や輸送費の低下等がもたらされ生産性が向上 する効果，生活環境が改善するなど生活の質が向上する 効果など, 整備されたインフラが機能することによって 得られる効果である.これはインフラが完成した後に継 続的かつ中長期的に生じる便益であるといえる.

中川ら ${ }^{11}$ は，交通整備が地域に及ぼす影響を市町村人 口の変化という観点から長期的かつ全国的なデータを用 いて実証的に分析した．この研究では，鉄道や高速道路 が整備された地域は他の地域に比べ市町村の人口増加率 が明らかに高く, さらに整備以前に集積がそしく人口規 模が小さかった市町村についても同様の効果が見られる ことを指摘している.

中里 ${ }^{12}$ は，道路整備が地域の経済成長に果たしてきた 役割について実証分析を行った.1960年代〜70年代に実 施された産業集積度の低い地域を含めた全国的な道路市 ットワーク整備が, 地域の市場規模の拡大や, 経済成長 に有意なプラスの影響を持つことを示した.

門間ら ${ }^{13}$ は，中国地方を縦断する高速路線である中国 自動車道, 山陽自動車道, 山陰自動車道（整備中）を対 象として, 各路線がそれぞれの地域に与える便益を推計 し, 中国自動車道, 山陽自動車道の山陽側2路線のみが 整備されている現状が山陰側地域に損失をもたらしてい ることを示した. このことから門間らは，効率の観点か ら整備効果の高い地域のみへのインフラ整備を行うこと は, 地域間の不均衡を拡大させるのであり, 公平性を損 
なう可能性があると指摘している.

小池ら ${ }^{14)}$ は，中国地方を対象に，過去に行われた高速 道路整備が人口変化や産業活動に与えた影響を定量的に 分析し，整備が行われた沿線を中心に地方全体において 製造業の活性化や発展に影響を及ぼした可能性を論じた。 一方で人口分布については，高速道路整備が都市部への 人口集積の一因となった一方で，中山間地域において人 口流出の原因となった可能性を指摘した.

要藤・吉村15) は，日本の非都心地域における高速道路 整備に着目した社会資本整備の地域経済への成長効果を 推定し, 高速道路整備によって地方都市へは長期的な成 長効果がもたらされることが確認された. さらに産業別 の効果に着目し，出荷額や販売額は，製造業や卸売業で は増える一方, 農業や小売業では道路整備を目的とした 用地買収や道路開通による労働力移動が原因となって減 少することを明らかにした。

長澤ら ${ }^{10}$ は，既に供用されている全ての高速道路が何 らかの理由である日突然利用不能となり，高速道路が分 担していた交通量全てを一般道に転換せざるを得ない場 合を仮想し，その場合における総走行時間，総走行経費， 燃料消費量の変化等といった交通面への影響に着目して その大きさを算定した。この結果，高速道路がない場合， 総走行時間及び総走行経費の増加による損失が年間 6.9 兆円に上ることが示された.

山内ら 8)は，森杉・大島 9のモデルを援用し，インフ ラ整備がもたらす経済及び交通量への影響の双方を整備 当初から時系列的に計算できるモデルを構築し，全国的 な整備の効果及び関東における整備の域内ならびに域外 への効果を推計した. 東名高速道路や中央自動車道等の 主要高速道路の開通が相次いだ 1960 年代後半から 1970 年代の間に費用便益比が急増しその後も増加しているこ と，高速道路が関東の社会経済に与えてきた影響は全国 と比較して特に大きいといえることを明らかにした。

ここまで，交通インフラ整備の効果或いは公共投資の 効果を扱った既往研究を概観した。しかしマクロ経済と 地域経済の双方において，公共投資のストック効果およ びフロー効果の双方について評価でき，かつ公共投資に よる経済成長効果を評価する上で考慮すべき市場におけ る需要と供給のインバランスがもたらす影響を勘案した モデルの構築は行われていなかった。これらを総合的に 評価できるモデルシステムを提案する研究として，根 津・藤井7)のものが挙げられる．根津・藤井の研究に先

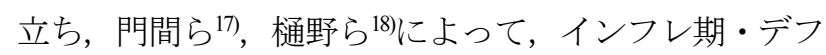
レ期といった経済トレンドや，道路投資額，道路整備量 を考慮し, インフラ整備後の国内総生産の変化などを推 計するマクロ計量経済モデルが提案されていたが，根 津・藤井はこれに地域単位の人口やGRPの推計を加えた モデルシステム（MasRAC）を構築し，交通インフラの
整備効果を多面的に分析する方法を提案し，リニア中央 新幹線をはじめとする未開業の新幹線路線整備等の評価 を行っている.

我が国においてこれまで進められてきた幹線交通網整 備は，国土全体に対し様々な影響をもたらしてきた。既 往研究が示唆する重要な事実は, 幹線交通網の沿線地域 においては人口や産業の集積など正の便益が発生する一 方で，それらの地域から離れた場所や，整備が行われて いない地域においては，人口や経済力に関して十分な波 及効果が得られないばかりか，場合によっては負の影響 すらもたらされるということである.つまり，今日まで に進められてきたような，首都圏に代表される国土の一 部地域を偏重したネットワーク整備は，都市部への一極 集中や地方の過疎化を促し，またこれに起因して災害時 のリスクが増大するといった弊害をもたらす恐れがある と言わざるを得ない.

インフラ整備の地域偏在の背景には, 国土の均衡ある 発展が目標とされたにもかかわらず，インフラ整備の効 果が適切に認識されていないせいで，結果的に十分な整 備が行われないという要因がある可能性がある. より具 体的に言うと，現状の評価方法では，公共投資の価值そ のものが過小評価されていることに加えて，地方分散効 果のような多面的な影響の評価が十分に行われず，政策 上必要な知見が提供されてこなかったため，交通網整備 の推進力が不足したのではないかと考えられる.

この現状を是正し，多極分散型の国土づくりを進める ためには，インフラ投資の多面的な効果に関する知見を 与える評価方法が必要で, その試みとして先述の MasRAC が提案されている. ところで，第 1 章において， 公共事業が十分に推進されない理由の一つとして, 過去 のインフラ整備の効果が十分に認識されていないという 可能性を指摘した. これについては，森杉・大島 9)や山 内ら ${ }^{8}$ の研究で, 高速道路網整備による GDPの増大効果 及び関東地域の高速道路整備による域内外への経済的効 果が示されている.しかし，交通網整備がもたらした全 国の各地域における人口や経済力分布といった「国土の バランス」に関する指標の変化は十分に明らかになって いない. また，事業実施によってもたらされるフロー効 果が考慮されていない点, それ故に, 一般均衡モデルに よる分析を行っておりデフレギャップやインフレギャッ プの存在といった需要と供給のインバランスが考慮され ていない点も課題として考えられる. MasRAC は, 過去 に整備された交通インフラが仮に存在しなかったとした 場合の地域間のアクセシビリティ（詳しくは後述する） の低下を考慮することで，「当該インフラが存在しなか つた場合の生産額の低下や人口分布の変化」を遡って推 計することが可能である，そこで本研究では，MasRAC を用いて既に供用されている高速道路が開通当初から今 
日にわたりもたらしてきた整備効果について，マクロ経 済及び人口等の地域間分布の双方の観点から評価を行う こととする

\section{MasRAC の概要とモデル内パラメータの推定}

本章では，本研究で用いるモデルシステム（MasRAC） の概要を説明する．モデルの詳細については，片岡らの 既往研究19)を照会されたい.

\section{(1) MasRACによるシミュレーションの概要}

本節では，MasRAC によるシミュレーション過程の概 要を説明する. MasRACでは，交通網整備を進めること で都市間移動の所要時間が短縮（次節に示寸式(1)の ACC（アクセシビリティ）が向上）し，人口，企業，都 市機能の集積や地域間交流の活発化による経済効果が, 整備沿線地域を中心に広く波及的にもたらされることを 想定している. なお当モデルでは効果の計上において, 一般的な費用便益分析のように各主体の便益を積みあげ るのではなく，フロー効果およびストック効果を GDP （GRP）の変動に帰着させ，その効果の夕に着目するこ とで，二重計上の発生を回避している.

モデルシステムの構造は図-1 に示した通りである.上 位モデルとなるマクロ経済モデルにおいて，アクセシビ リティや公共投資額の増減が日本全体へ及ぼすマクロ経 済効果（GDP）を推計した上で，下位モデルの地域モデ ルにおいて, 各地域の人口及び域内総生産（GRP）を推 計する構造となっている.

\section{(2) アクセシビリティ（ACC）について}

本研究では，各地域間の移動に要寸る時間に着目した， 片岡らの既往研究 ${ }^{19}$ で提案されている以下の式(1)によっ て定義される地域アクセシビリティ（ACC）を用いる. またこれを集計したものとして，式(2)で定義される全 国アクセシビリティを用いる.アクセシビリティは, 道 路と鉄道それぞれについて算出し，独立した変数として 用いる.

根津・藤井の既往研究 》では, 道路 ACC と鉄道 ACC を合成する手法が用いられていたが，その際の手段分担 率は旅客流動調査に基づいており，貨物輸送を勘案でき ていなかった。鉄道は旅客輸送に用いられる割合が高く， 都市間の道路は貨物輸送に供される割合が高いことを始 めとして, 様々な要因により鉄道と道路の整備がもたら 寸影響には違いが存在することも考えられる。この違い を反映するため, 片岡らの研究で提案されたのが，費用 項を統合せず各推計に道路 $\mathrm{ACC}$ と鉄道 $\mathrm{ACC}$ を独立の変 数として投入する手法である. 本研究でもこの手法を用

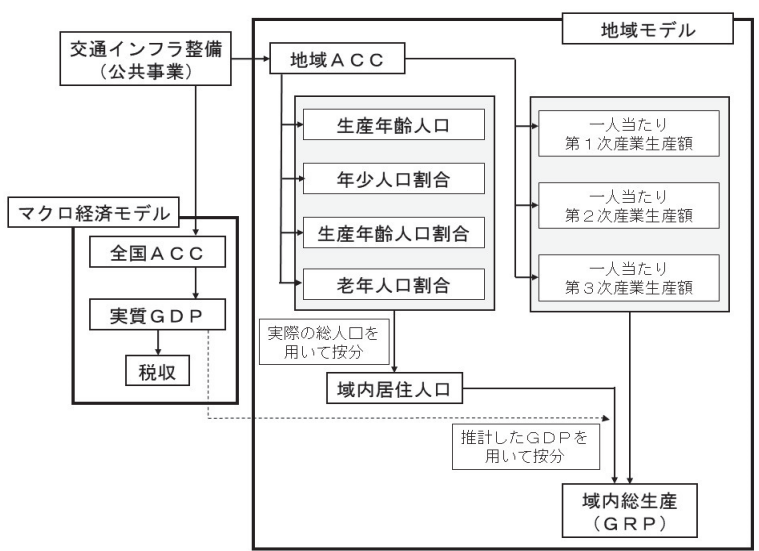

図-1 MasRAC 概要図

いることとする.

地域の単位として用いる生活圈は，国土交通省の全国 幹線旅客純流動調查における地域区分として用いられて いる 207 生活圈ゾーン ${ }^{20)}$ である. 式内の生活圈人口

$\left(P O P_{j}\right)$ には, 2010 年の国勢調査データを用いている。 各生活圈間の所要時間 $\left(t_{i j}\right)$ は, 国土交通省が提供す る総合交通分析システム（NITAS）によって算出した各 生活圈ゾーン中心（生活圈内に都道府県庁がある場合は 都道府県庁，ない場合は人口が最大の市町村の役場）間 の最短所要時間を用いる.

$$
\begin{gathered}
A C C_{i}^{k}=\sum_{j} \frac{P O P_{j}}{t_{i j}} \\
A C C^{k}=\frac{\sum_{i} P O P_{i} \times A C C_{i}^{k}}{\sum_{i} P O P_{i}}
\end{gathered}
$$

$A C C_{i}^{k}$ : 交通手段 $k$ についの生活圈iの地域アクセシビ リティ

$P O P_{j}:$ 生活圈 $j$ の居住人口

$t_{i j}$ : 生活圈 $i$ から生活圈 $j \backsim の$ 所要時間

$A C C^{k}$ : 交通手段 $k$ にいての全国アクセシビリティ

$k:$ 道路, 鉄道

\section{(3) MasRACマクロ経済モデルの概要}

モデルの構造は図-2に示した通りである. まず需要項 目別に実質 GDP（需要）の推計を行う。また民間企業 設備投資から推計した民間資本ストック，雇用者報酬か ら推計した労働人口を用いて, 稼働率や失業率を考慮し て潜在（供給）GDP の推計を行う。これら実質 GDP と 潜在 GDP を比較することで，ギャップ変数（インフレ ギャップ及びデフレギャップ）を算定し，これを用いて 需要項目別のデフレータ等の物価変数を推計する. さら にこの物価変数によって GDP デフレータを算定し，米 


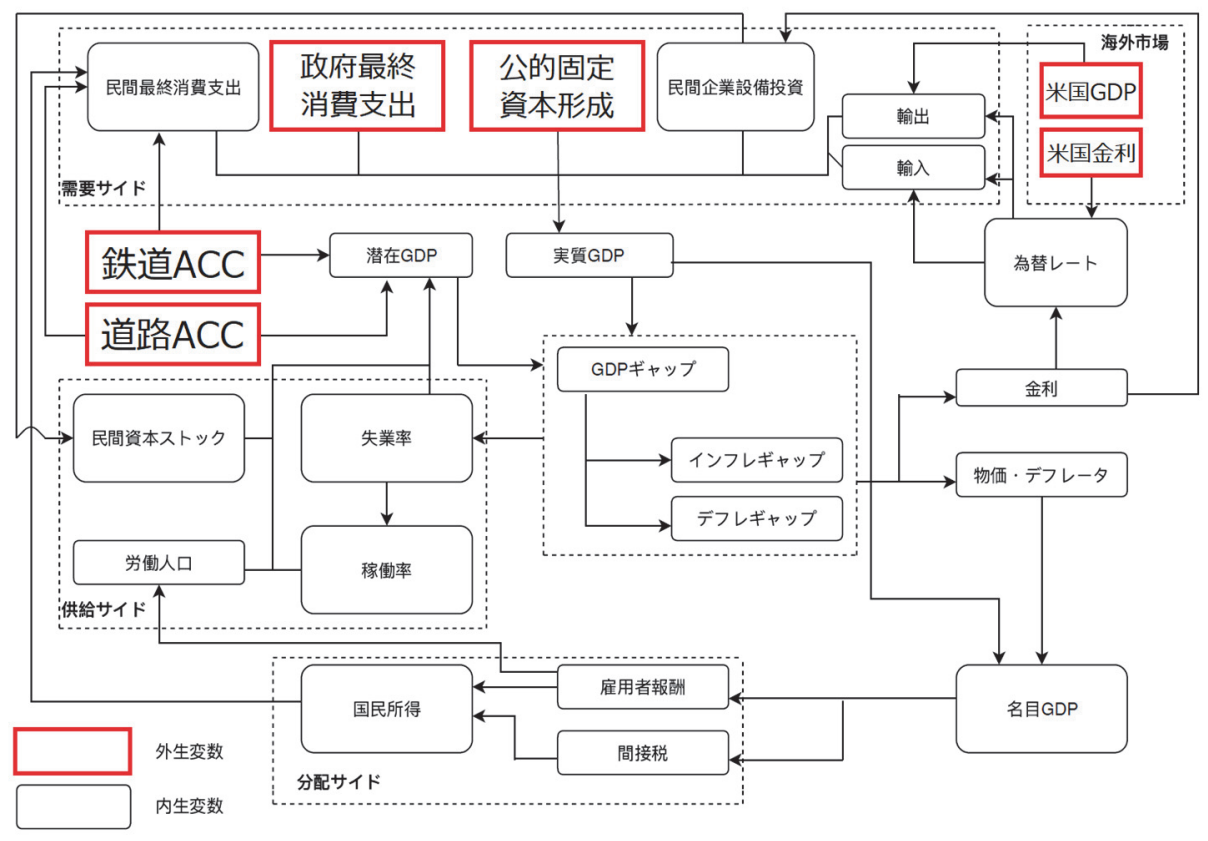

図-2 マクロモデル概要図

国 GDP と合わせて輸入額が求められる.これらによっ て実質 GDP を推計する. 当モデルの特徵として, 交通 インフラ網整備によるアクセシビリティ（ACC）向上の 影響に着目している点，公共投資額の変化に応じた実質 GDP の推計を行う点, インフレやデフレといったマク ロ経済トレンドによって公共投資の乗数効果が異なるこ とを考慮した変数を内在化している点が挙げられる．ま た運輸部門と他部門の関係を独立してモデル化せず，交 通に関わる社会資本ストックを ACC 指標として評価し これが生産や消費を円滑化するというモデル構造を採っ ている. 本来は, ACC 指標の向上が生産性を改善し, それを通して生産や消費に影響を与えると思われるが， 本研究では上記のモデル構造を仮定した上で，そのパラ メータを実データに適合させることを通して推計し， $\mathrm{ACC}$ 指標による生産や消費に対する諸種の間接効果を 総合した効果を直接的に推計するというアプローチを採 用する.

また当モデルでは, 公的固定資本形成とアクセシビリ ティを独立した変数として投入している．これはすなわ ち，予測時および推計時の双方で両データを外生データ として準備する形でモデルを構築し，運用することを想 定することを意味している. したがって，モデルの推計 時に適切な ACC と公的固定資本形成のデータを準備で きるなら，すなわちこれだけの道路をつくるから公的固 定資本形成はこれくらい増えることになる，ということ を加味した外生データを用意できるなら，推計時のパラ メータを予測時に活用することで大きな予測バイアスが
生ずることは回避できるものと考えられる.

なおマクロモデルの推定は 1985 年以降で行った. こ れは 1985 年以前のデータを用いた推定では, 推計結果 の精度が安定しなかったためである。また実質 GDP は, 平成 23 暦年連鎖価格の值を用いている.

またマクロ経済モデル及び後述の地域モデルでは，片 岡ら ${ }^{19}$ の提案する「アクセシビリティの 10 年移動平均 化」，すなわち式(1)または(2)によって年次毎に算出さ れたアクセシビリティを暫定值とし，過去 10 年の暫定 值の平均を当該年次のアクセシビリティ值とする操作を う。これは各年次のアクセシビリティを各モデルにその まま用いることで，交通インフラの供用開始直後にアク セシビリティの急激な向上効果がもたらされ，産業形態 や人口分布が急激に変化する非現実的な推計結果が得ら れることを避けるためである. 移動平均を行う期間につ いては, 本研究で採用している 10 年平均のほか， 5 年平 均も検討したが，調整済み $\mathrm{R}^{2}$ 值は 5 年平均の場合消費 関数で 0.958 , 生産関数 $0.946,10$ 年平均では消費関数で 0.986, 生産関数 0.981 となっており，10 年平均が一定高 いデータへの適合度を示したことから，10 年平均を用 いることとした.

\section{(4) MasRAC地域モデルの概要}

地域モデルでは，まず生活圈内人口推計モデルによっ て各地域の人口を推計し, その後域内総生産推計モデル によって域内総生産を推計することで, 幹線交通網整備 による人口分布ならびに地域の経済力やの変化を評価す 
る. なお地域の単位としては, 人口推計では 207 生活圈 ゾーンを，域内総生産推計ではデータの制約上都道府県 を用いる. また各地域の居住者は，当該地域内で労働に 従事しているものと仮定している.

地域モデルの各モデルでは，ACC 他を説明変数とす る重回帰モデルを構築するが，その際に用いるダミ一変 数の定義を表-1 に示す. 各ダミーは該当する場合に 1 , それ以外の場合に0の值をとる.

\section{a) 生活圏内人口推計モデル}

第 2 章で示した既往研究でも述べたように, 高速道路 の整備有無の違いによって各地域で人口の流出入が起こ

\section{表-1 各ダミーの定義}

\begin{tabular}{ll} 
地域ダミー & 対象地域 \\
\hline 北海道 & 北海道 \\
東北 & 東北地方礻 \\
北関東 & 茨城, 栃木, 群馬県 \\
南関東 & 東京都, 埼玉, 千葉, \\
& 神奈川, 山梨県 \\
北陸信越 & 新潟, 富山, 石川, 福井, \\
東海 & 長野県 \\
近畿 & 岐皁, 静岡, 愛知, 三重県 \\
中国 & 近畿地方二府四県 \\
四国 & 中国地方五県 \\
九州 & 四国四県 \\
& 九州八県 \\
都市ダミ一 & 対象地域 \\
県庁所在地 & 都道府県庁が存在する \\
& 生活圈 \\
政令指定都市 & 全国20の政令指定都市が存 \\
& 在する生活圈
\end{tabular}

り, 人口分布に変化が発生すると考える. 労働力となる 生産年齢人口（15 歳以上 65 歳未満）は, 高速道路整備 による産業の集積が進むことにより整備沿線地域で増加 すると考えられる一方, 老年人口（65 歳以上）は産業 集積の影響を受けにくく必ずしも増加しないと考えられ る等，年齢層によって整備による人口の推移は異なる可 能性が考えられる.このため本モデルでは, 年少人口

（15歳未満），生産年齢人口，老年人口の 3 階層に分類 して推計を行う。また人口推計では 207 生活圈ゾーンを 地域の単位として用いるが, 人口の絶対数は生活圈によ って大きく異なっている，乙れを考慮するため，生産年 齢人口の絶対数および各人口階層が域内総人口に占める 割合を本項で示寸各モデルを用いてそれぞれ推計し，こ れらから各生活圈の域内居住人口を暫定的に算出寸る. さらにその総和が実際の全国人口と整合するよう調整を 行う. パラメータ推定結果は表-2に示した通りである. パラメータ推定には，1980年以降の国勢調査を用いてい る.

生産年齢人口推計では, 道路 $\mathrm{ACC}$ や鉄道 $\mathrm{ACC}$ が向上 すれば生産年齢人口が増加するという論理的に整合性の とれた結果となった。 年少人口割合推計では, 道路 $\mathrm{ACC}$ のパラメータが負であるのに対し，鉄道 ACC のパ ラメータが正となっているが, これは 15 歳未満の世代 が，道路整備によるマイカー利用等における利便性の向 上の恩恵を成年世代に比べて受けにくい一方で，公共交 通機関である鉄道の利便性向上の影響を受けや寸い可能 性を考慮すると，十分に説明できる結果だと考えられる. 生産年齢人口割合推計では, 道路 ACC のパラメータが 負となっているが，生産年齢人口の絶対数についての道 路 ACC のパラメータが正となっていることから, 道路

表-2 生活圈内人口推計モデルパラメータ推定結果

\begin{tabular}{|c|c|c|c|c|c|c|c|c|c|c|c|c|}
\hline \multirow[b]{2}{*}{ 説明変数 } & \multicolumn{3}{|c|}{ 生産年齢人口推計 } & \multicolumn{3}{|c|}{ 年少人口割合推計 } & \multicolumn{3}{|c|}{ 生産年齢人口割合推計 } & \multicolumn{3}{|c|}{ 老年人口割合推計 } \\
\hline & 推定值 & t值 & & 推定值 & $\mathrm{t}$ 值 & & 推定値 & t值 & & 推定值 & 值 & \\
\hline 定数 & $1.07 \times 10^{1}$ & 167.08 & $* *$ & -1.76 & -125.79 & $* *$ & $-5.25 \times 10^{-1}$ & -100.77 & $* *$ & -1.47 & -59.79 & $* *$ \\
\hline 道路 $\mathrm{ACC}$ & $1.76 \times 10^{-6}$ & 5.23 & $* *$ & $-6.53 \times 10^{-7}$ & -8.92 & $* *$ & $-1.06 \times 10^{-7}$ & -3.90 & $* *$ & $6.24 \times 10^{-7}$ & 4.85 & $* *$ \\
\hline 鉄道ACC & $1.58 \times 10^{-6}$ & 11.26 & $* *$ & $1.91 \times 10^{-7}$ & 6.27 & $* *$ & $1.24 \times 10^{-7}$ & 10.94 & $* *$ & $-4.74 \times 10^{-7}$ & -8.86 & $* *$ \\
\hline インフレ率 & $3.40 \times 10^{-2}$ & 5.20 & $* *$ & $5.70 \times 10^{-2}$ & 39.57 & $* *$ & $8.00 \times 10^{-3}$ & 14.78 & $* *$ & $-9.20 \times 10^{-2}$ & -36.47 & $* *$ \\
\hline 北海道地域ダミー & $1.92 \times 10^{-1}$ & 2.61 & $* *$ & $-1.49 \times 10^{-1}$ & -9.28 & $* *$ & $5.70 \times 10^{-2}$ & 9.50 & $* *$ & $-1.04 \times 10^{-1}$ & -3.70 & $* *$ \\
\hline 東北地域ダミー & $-5.50 \times 10^{-2}$ & -0.79 & & $-4.70 \times 10^{-2}$ & -3.09 & $* *$ & $2.20 \times 10^{-2}$ & 3.93 & $* *$ & $-2.40 \times 10^{-2}$ & -0.89 & \\
\hline 北関東地域ダミー & $-6.30 \times 10^{-1}$ & -5.45 & $* *$ & $9.50 \times 10^{-2}$ & 3.77 & $* *$ & $4.60 \times 10^{-2}$ & 4.91 & $* *$ & $-1.78 \times 10^{-1}$ & -4.02 & $* *$ \\
\hline 南関東地域ダミー & $-5.49 \times 10^{-1}$ & -4.16 & $* *$ & $1.02 \times 10^{-1}$ & 3.56 & $* *$ & $5.90 \times 10^{-2}$ & 5.50 & $* *$ & $-2.52 \times 10^{-1}$ & -5.00 & $* *$ \\
\hline 北陸地域ダミー & $-5.20 \times 10^{-1}$ & -6.25 & $* *$ & $-1.10 \times 10^{-2}$ & -0.60 & & $7.00 \times 10^{-3}$ & 0.99 & & $2.80 \times 10^{-2}$ & 0.88 & \\
\hline 東海地域ダミー & $-5.26 \times 10^{-1}$ & -5.21 & $* *$ & $4.10 \times 10^{-2}$ & 1.86 & & $1.70 \times 10^{-2}$ & 2.01 & $*$ & $-5.30 \times 10^{-2}$ & -1.38 & \\
\hline 近畿地域ダミー & $-8.22 \times 10^{-1}$ & -8.05 & $* *$ & $4.50 \times 10^{-2}$ & 2.04 & $*$ & $1.10 \times 10^{-2}$ & 1.32 & & $-4.40 \times 10^{-2}$ & -1.13 & \\
\hline 中国地域ダミー & $-5.25 \times 10^{-1}$ & -6.84 & $* *$ & $-7.60 \times 10^{-2}$ & -4.54 & $* *$ & $-1.60 \times 10^{-2}$ & -2.60 & $* *$ & $1.32 \times 10^{-1}$ & 4.49 & $* *$ \\
\hline 四国地域ダミー & $-4.58 \times 10^{-1}$ & -5.44 & $* *$ & $-9.60 \times 10^{-2}$ & -5.23 & $* *$ & $-8.00 \times 10^{-3}$ & -1.20 & & $1.11 \times 10^{-1}$ & 3.44 & $* *$ \\
\hline 県庁所在地ダミー & 1.06 & 22.09 & $* *$ & $6.00 \times 10^{-3}$ & 0.62 & & $3.60 \times 10^{-2}$ & 9.27 & $* *$ & $-1.11 \times 10^{-1}$ & -6.07 & $* *$ \\
\hline 政令指定都市ダミー & $5.83 \times 10^{-1}$ & 7.95 & $* *$ & $-1.40 \times 10^{-2}$ & -0.90 & & $1.60 \times 10^{-2}$ & 2.61 & $* *$ & $-7.90 \times 10^{-2}$ & -2.81 & $* *$ \\
\hline 調整済みR²值 & 0.6 & & & 0.55 & 56 & & 0.38 & & & 0.5 & & \\
\hline
\end{tabular}


表-3 各産業 1 人当たり生産額推計モデルパラメータ推定結果

\begin{tabular}{|c|c|c|c|c|c|c|c|c|c|}
\hline & \multicolumn{3}{|c|}{ 第1次産業 } & \multicolumn{3}{|c|}{ 第2次産業 } & \multicolumn{3}{|c|}{ 第3次産業 } \\
\hline 説明変数 & 推定值 & t值 & & 推定值 & $\mathrm{t}$ 值 & & 推定値 & t值 & \\
\hline 定数 & -2.09 & -17.07 & $* *$ & -1.71 & -12.73 & $* *$ & -6.00 & -4.29 & ** \\
\hline 道路ACC & $-6.31 \times 10^{-7}$ & -1.07 & & $2.86 \times 10^{-6}$ & 3.64 & $* *$ & $4.57 \times 10^{-6}$ & 5.58 & $* *$ \\
\hline 鉄道ACC & $-7.05 \times 10^{-7}$ & -2.39 & $*$ & $1.20 \times 10^{-6}$ & 3.07 & $* *$ & $2.15 \times 10^{-7}$ & 0.53 & \\
\hline 農作物作付面積 & $-6.68 \times 10^{-7}$ & -1.14 & $* *$ & & & & & & \\
\hline インフレ率 & $3.00 \times 10^{-3}$ & 0.37 & & $-8.40 \times 10^{-2}$ & -8.16 & $* *$ & $-1.22 \times 10^{-1}$ & -11.39 & $* *$ \\
\hline 北海道地域ダミー & $7.65 \times 10^{-1}$ & 1.25 & & $4.40 \times 10^{-1}$ & 1.60 & & $5.45 \times 10^{-1}$ & 1.91 & \\
\hline 東北地域ダミー & $3.31 \times 10^{-1}$ & 2.93 & $* *$ & $-1.22 \times 10^{-1}$ & -0.84 & & $-3.35 \times 10^{-1}$ & -2.22 & $*$ \\
\hline 北関東地域ダミー & $4.33 \times 10^{-1}$ & 2.47 & $*$ & $-5.63 \times 10^{-1}$ & -2.49 & $*$ & -1.51 & -6.42 & $* *$ \\
\hline 南関東地域ダミー & $-7.02 \times 10^{-1}$ & -3.67 & $* *$ & -1.54 & -6.05 & $* *$ & -2.07 & -7.81 & $* *$ \\
\hline 北陸地域ダミー & $-5.90 \times 10^{-2}$ & -0.47 & & $-1.64 \times 10^{-1}$ & -0.99 & & $-6.73 \times 10^{-1}$ & -3.89 & $* *$ \\
\hline 東海地域ダミー & $-6.10 \times 10^{-2}$ & -0.41 & & $-5.81 \times 10^{-1}$ & -2.90 & $* *$ & -1.23 & -5.92 & $* *$ \\
\hline 近畿地域ダミー & $-7.31 \times 10^{-1}$ & -5.19 & $* *$ & $-7.46 \times 10^{-1}$ & -4.04 & $* *$ & -1.24 & -6.47 & $* *$ \\
\hline 中国地域ダミー & $-1.85 \times 10^{-1}$ & -1.57 & & $-4.50 \times 10^{-2}$ & -0.29 & & $-3.71 \times 10^{-1}$ & -2.31 & $*$ \\
\hline 四国地域ダミー & $1.04 \times 10^{-1}$ & 0.83 & & $-1.10 \times 10^{-1}$ & -0.68 & & $-3.26 \times 10^{-1}$ & -1.93 & \\
\hline 調整済夕知值 & $\overline{0.42}$ & & & *:5\%有意， & $* *: 1 \%$ & & & & \\
\hline
\end{tabular}

ACC の向上により各年齢階級を合わせた地域内総人口 の増加をもたらすという，十分に解釈可能な結果である と考えられる。老年人口割合推計では，道路 ACC のパ ラメータが正，鉄道 ACC のパラメータが負となってい る. これについては, 乗り換えなど目的地へのアクセス において不便の多い公共交通機関の鉄道の利便性向上の 恩恵を老年世代は若年世代に比べて受けにくいことや， 東京や大阪等の大都市圏においては老年世代が超過流出 となっているが21), その流出先としてマイカーの利便性 が高い地域が好まれる可能性等が考えられる.

\section{b) 域内総生産 (GRP) 推計モデル}

高速道路の整備によって, 輸送時間の削減やこれに伴 う然料費やドライバーの人件費といった輸送コストの軽 減，また産業の集積等がもたらされ，域内の労働生産性 が向上するといった変化を想定する．ところで，この変 化は産業の様態によって大きく異なると考えられる．第 1 次産業の場合, 生産活動が自然環境に依存しているこ とや，要藤・吉村 ${ }^{150}$ の既往研究で述べられていたように 道路整備によって農業産出額に負の効果がもたらされる 場合があることを踏まえると，高速道路整備による生産 性向上の度合いは必ずしも大きくないと考えられる。一 方，製造業をはじめとする第 2 次産業は，高速道路整備 によって製品の輸送効率が高まることで，労働生産性が 大きく向上することが考えられる.

そこで本モデルでは，高速道路整備によってもたらさ れる生産性向上等による成長効果の産業による違いを評 価できるよう, 第 1 次, 第 2 次, 第 3 次産業の 3 分類に ついて，それぞれの一人当たり生産額を推計する. その

後, これら推計值に生活圈内人口推計モデルにより算出 した域内人口を乗ずることで各生活圈の域内総生産

（GRP）を暫定的に算出する. さらにその総和がマクロ 経済モデルで推計した実質 GDP と整合するよう，実質 GDP の推計值を用いて調整を行う。パラメータ推定結 果は表-3 に示した通りである. パラメータ推定には, 1960年以降の国勢調査及び内閣府県民経済計算のデータ を用いた。

第 1 次産業 1 人当たり生産額推計では, 道路 $\mathrm{ACC}$ の パラメータは有意でないが，これは第 1 次産業の立地が 自然環境に依存しており，交通利便性の影響を受けにく い可能性を考慮すると十分に説明可能な結果であると言 える. 鉄道 ACC のパラメータが負であることについて も，第 1 次産業が鉄道の利便性が比較的低い地域に集積 する産業であることを踏まえると，理に適った結果であ ると考えられる. 第 2 次産業 1 人当たり生産額推計では, 道路 ACC，鉄道 ACC のパラメータはともに正に有意と なっており，交通利便性の向上が物流の効率化等による 生産性向上をもたらすという論理的に整合性のある結果 だと考えられる. 第 3 次産業 1 人当たり生産額推計では, 道路 ACC のパラメータは正かつ有意であり，道路の利 便性向上が各種産業の生産性向上に資するという論理的 に整合性のある結果と言える．鉄道 ACC のパラメータ は有意でないが，これは第三次産業にはその定義上様々 な産業が含まれており，道路に比べ利用が限定的な鉄道 の利便性向上は必ずしも生産性の向上に影響を与えない 可能性を示唆していると考えられる.

なお本項で述べた域内総生産推計モデルによって推計 
された各都道府県の GRP の全国合計，すなわち整合調 整前の GDP の推計期間を通じた平均は 454 兆円, 前節 で述べたマクロモデルによって推計された GDP の平均 は 457 兆円となっており, 両者の乘離はマクロモデルの 推計值の $0.65 \%$ という低い水準となっている.

\section{4. 既存高速道路の整備効果推計及び分析}

まず既存の高速道路路線の一部または全部が仮に整備 されていなかった場合を想定し，マクロ経済及び地域の 人口や経済力の分布がじのように現実と異なっていたか についてMasRACを用いた推計を行う。そして，これら の指標について不通路線無し（実際）の場合と比較する ことで, 既に供用されている高速道路が開通当初から今 日にわたりもたらしてきた整備効果を評価する.

分析の対象とする期間は, 日本初の高速道路である名 神高速道路が開通寸る以前の1961年から2015年とした.

\section{(1) 分析対象とする高速道路路線}

以下の 3 シナリオを想定する.

[1] 我が国において最も初期に整備され, 三大都市圈 を結ぶ基幹路線である, 東名高速道路, 名神高速 道路（約 $540 \mathrm{~km}$ ) 及びそれらの並行路線として整備 が進められている新東名高速道路, 新名神高速道 路の全区間（2015年時点の供用延長 : 約 210km）が 整備されなかった場合

[2] 首都圈, 中部地方, 関西圈を結ぶ路線網に含まれ る高規格幹線道路（図-3 の赤線部）（2015 年時点 の供用延長 : 約 $2,700 \mathrm{~km}$ ）が整備されなかった場合

[3] 2015 年 3 月末までに整備された高規格幹線道路の 全路線（2015 年時点の供用延長 : 約 11,000km） が 整備されなかった場合

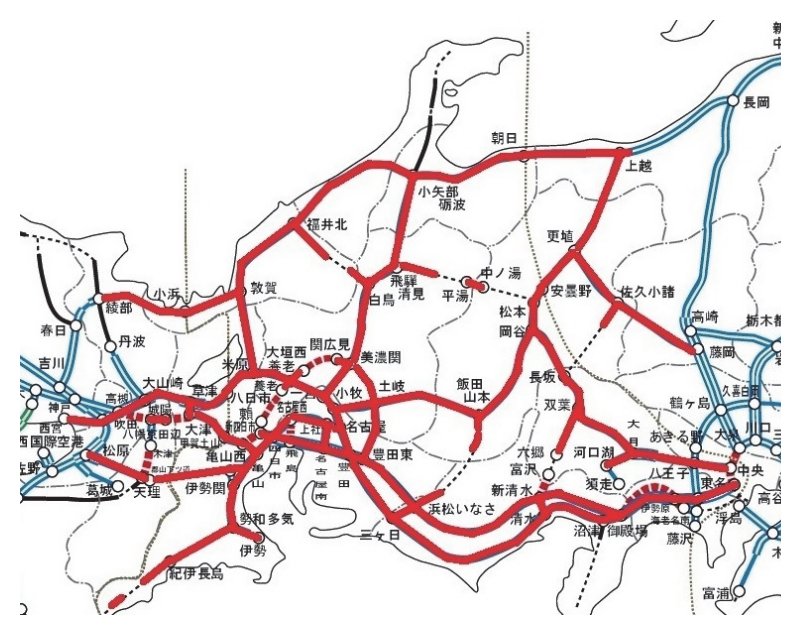

図-3シナリオ[2]で未整備とする路線
なお高規格幹線道路は, 四全総で高規格幹線道路網を 形成する路線として定められた, 高速自動車国道（A 路 線），高速自動車国道に並行する一般国道自動車専用道 路（A'路線），国土交通大臣指定に基づく高規格幹線道 路（一般国道の自動車専用道路）（B 路線）及び本州四 国連絡道路を指寸。

\section{（2）路線不通による交通量変化の考慮}

ある高速道路路線が整備されていなかった場合の影響 の一つとして, 所要時間, 延いてはアクセシビリティに 変化を与えうる他の道路路線の交通量変化を考慮する必 要がある. 未整備路線の代替となりうる高速道路路線, あるいは一般道路路線では, 当該路線が分担していた交 通量が流入寸ることによる交通量の増加が想定される. 一方で，こうした道路によるアクセスの不便さから鉄道 などの他の輸送機関が輸送量を分担することとなり, 自 動車が担う交通量自体が減少する可能性も考えられる. 道路が未整備であったと想定した場合の交通量の変化は, このように多様な要因を孕むため, これらを全て考慮し た推計を行うには潜在需要（induced demand）・抑圧需要 (depressed demand)の存在を加味した上で, 様々な歴年デ ータを用いた交通需要モデルを構築することが必要とさ れる. そうした交通需要予測も重要な課題であるものの, 本研究では, 既存高速道路の効果を経済の視点から評価 する研究の第一段階として, 潜在需要・抑圧需要の存在 を考慮しない場合においても, 寸なわち, 高速道路が存 在しない場合に，現在高速道路を利用している自動車が 別経路を利用するようになると仮定した場合においても， 既存高速道路がどの程度の経済的価值を持つのかを明ら かにすることを目指すこととした，言うまでもなく，潜 在交通・抑圧交通を考えれば，地域間の自動車 OD 交通 量それ自身が縮小し，それが経済活動をさらに抑圧させ る効果を持つことが想定される. したがって, 潜在交 通・抑圧交通を考慮しない本研究の検討結果は, 既存高 速道路の経済価值の実際の水準よりも小さく評価寸る可 能性があり, 逆に言うと, 潜在交通・抑圧交通を考えれ ば，その価值はさらに大きなものとなる可能性が想定さ れる．ただし本モデルでは混雑関数を組み込んでいない． 混雑の評価を考慮した場合, 交通需要の増加が便益をむ しろ低下させるケースがありうる点については留意が必 要である.

表-4 混雑度と旅行速度関倸推定結果

\begin{tabular}{lrrr} 
& $\mathrm{a}$ & $\mathrm{b}$ & \multicolumn{2}{c}{ 調整済み $\mathrm{R}^{2}$ 値 } \\
\hline 2車線の自専道 & -3.69 & 80.4 & 0.012 \\
3車線以上の自専道 & -16.70 & 97.0 & 0.181 \\
2車線の非自専道 & -9.78 & 42.0 & 0.124 \\
\hline & \multicolumn{2}{c}{ パラメータはいずれも1\%有意 }
\end{tabular}


以上の前提に基づき，まず道路の混雑度と旅行速度の 関係について, 混雑度 $k$ を説明変数, 旅行速度（昼間 12 時間平均旅行速度の上下線平均） $v$ を従属変数とする単 回帰モデル $(v=a k+b, a$ 及び $b$ はパラメータ $)$ を 2 車線の 自動車専用道路, 3 車線以上自動車専用道路, 2 車線の 一般道路の 3 分類についてそれぞれ推定を行った. 推定 結果は表-4 のとおりである. 推定には, 平成 27 年度の 全国道路・街路交通情勢調査（道路交通センサス）の一 般交通量調査集計表のデータを用いた.

続いて未整備路線設定時の交通量（昼間 12 時間自動 車類交通量, 上下合計）について, 次の通り推計した. 愛知，岐阜，富山県の東側県境を今回取り上げる代表的 な断面とし，同断面を通過する路線の交通量について検 討を行う。各未整備シナリオにおいて，未整備とした路 線が受け持っていた交通量が，そのほかの路線にそれら 路線が受け持っていた交通量に比例して分配されるとし て，各シナリオにおける交通量，混雑度を推計する。 な お 2 車線に満たない狭隘路線は交通量分配の対象外とし た. そしてこれらの結果を用いて，各シナリオでの各路 線の旅行速度変化率を求めその平均をとると, シナリオ [1]では-7.8\%，シナリオ[2]およびシナリオ[3]では-23.4\%と なった. この值を未整備路線の存在する生活圈の生活圈 ACCに対して用いた.

\section{(3) マクロ経済モデルによる推計結果の比較}

本節では，マクロ経済モデルによる実質 GDP の推計 結果について述べる. マクロ経済モデルでは，交通イン フラ整備に伴う公共投資および各地域のアクセシビリテ イの向上が，どの程度実質 GDP の向上に寄与するかを 評価する.

不通なし (実際) の場合および各不通シナリオについ て，実質 GDP の推計を行った. 安定した精度で結果が 得られている 1985 年以降の推計值を示す.

不通無し (実際) 及び各不通シナリオの実質 GDP 推

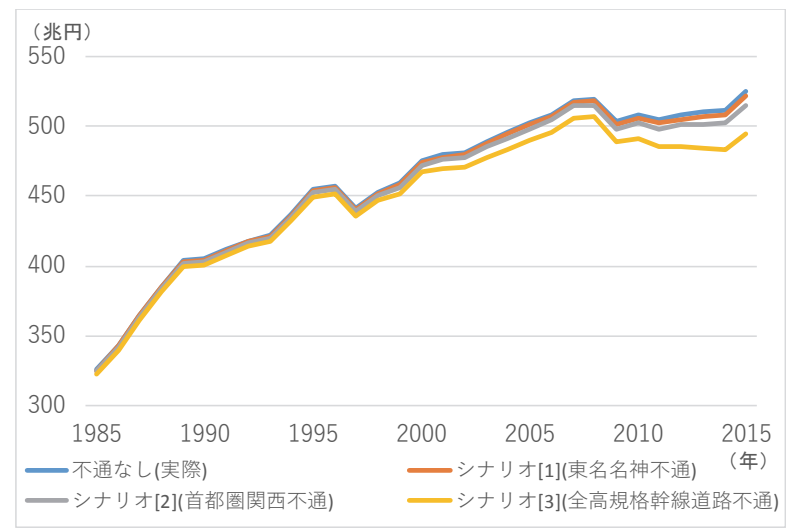

図-4 実質 GDP 推計結果
計值の推移は図-4 のとおりである. 2015 年の実質 GDP は，不通無し (実際) と比較してシナリオ[1]で約 4.4 兆 円 (約 0.8\%)，シナリオ[2]で約 10.5 兆円（約 2.0\%）， シナリオ[3]で約 31.6 兆円（約 6.0\%）減少することが確 認された. また 1985 年から 2015 年の累計では，不通無 し (実際) に比べてシナリオ[1]で約 49.4兆円，シナリオ [2]で約 117.6兆円，シナリオ[3]で約 333.5 兆円の減少とな っている.

\section{（4）地域モデルによる推計結果の比較}

地域モデルにおいても，マクロ経済モデルと同様の 3 つの不通シナリオについて, 各地域の人口ならびにGRP の推計を行い, 不通無し (実際) の場合との比較を行う。 なおここでの各地域の定義は，地域ダミ一の定義（表-1） と同様である.

\section{a) 人口分布の変化}

シナリオ[1]では，不通無しの場合に比べ南関東，東 海, 近畿の 3 地域で人口が減少しており，その数は2015 年時点でそれぞれ約 85 万人 $(-2.6 \%)$ ，約 130 万人 $(-8.8 \%)$ ，約 101 万人 $(-4.2 \%)$ であることが確認され た. シナリオ[2]では，同じ 3 地域において不通無しの場 合に比べて人口が減少しており，その数は同じく 2015 年時点でそれぞれおよそ 276 万人 $(-8.4 \%) ， 236$ 万人 (-16.0\%)，118 万人 (-4.8\%) であることが確認された. さらに北陸信越地域においても 90 年代以降に人口が減 少していることが確認された。 シナリオ[3]では，不通 無しの場合に比べて北関東, 南関東, 東海, 近畿の各地 域で人口が減少しており，その数は同じく 2015 年時点 でそれぞれおよそ 29 万人 $(-4.3 \%) ， 362$ 万人 (-11.0\%)， 91 万人 $(-6.1 \%) ， 232$ 万人 $(-9.6 \%)$ であることが確認 された. 図-5は，不通無し (実際) 及び各不通シナリオ において推計された，2015年の各地方の人口である. 図 -6, 図-7, 図-8 はそれぞれ，不通なし (実際) に対する シナリオ[1], シナリオ[2], シナリオ[3]における各地方 の人口の増減率(\%)を示したものである.

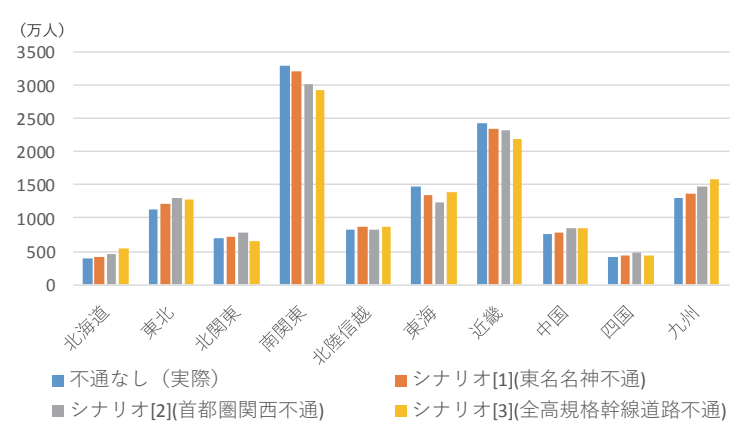

図-5 地方別居住人口（2015 年） 


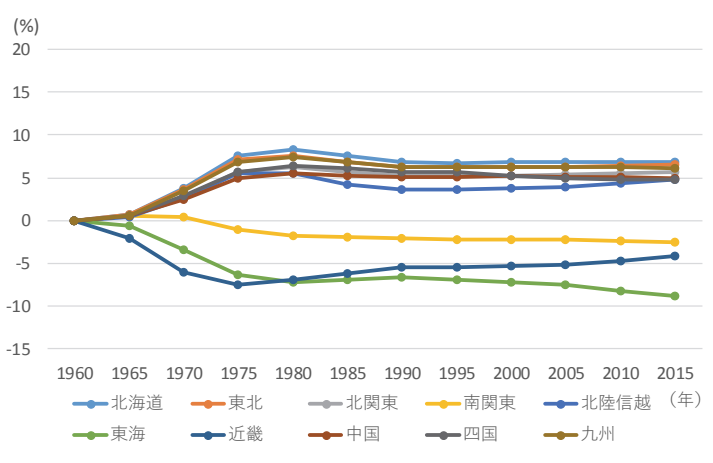

図-6 不通なしに対するシナリオ[1]の人口増減率

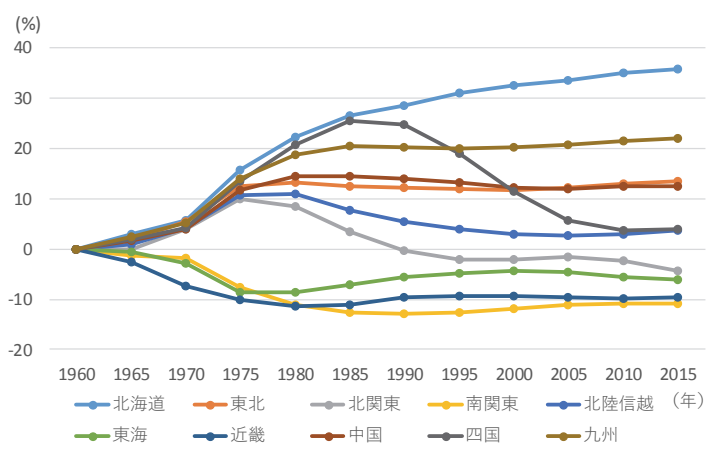

図-8 不通なしに対するシナリオ[3]の人口増減率

\section{b) 域内総生産 (GRP) の変化}

シナリオ[1]では，不通無しの場合に比べ南関東，東 海，近畿の3地域でGRPが減少しており，その額は2015 年時点でそれぞれおよそ 12.3 兆円 $(-8.0 \%) ， 12.0$ 兆円 (-22.3\%)， 15.0 兆円 (-9.4\%) であることが確認された シナリオ[2]では，同じ3 地域において不通無しの場合に 比べて GRP が減少しており，その額は同じく 2015 年時 点でそれぞれおよそ 30.9 兆円 $(-20.2 \%) ，-21.6$ 兆円 (-39.9\%)，-26.5 兆円（-16.6\%）であることが確認され た. さらに北陸信越地域においても 90 年代以降に GRP が減少していることが確認された。これらシナリオでは, 東北, 北関東, 九州で GRP の大きな増加が確認された。 シナリオ[3]では，不通無しの場合に比べて北関東，南 関東，東海，近畿の各地域で GRP が減少しており，そ の額は同じく 2015 年時点でそれぞれおよそ-1.9 兆円 $(-8.1 \%) ， 48.2$ 兆円 $(-31.5 \%) ， 7.8$ 兆円 $(-14.5 \%)$, 45.1 兆円（-28.3\%）であることが確認された。一方北海 道や東北，九州では大きく GRP が増加していた. 図-9 は，不通無し (実際) 及び各不通シナリオにおいて推計 された, 2015 年の各地方の GRPである.

GRP については，マクロモデルによる実質 GDP の推 計結果を用いるため，1985年以降についてのみ推計を行 ったが，この期間の増減率の推移は図-6, 図-7, 図-8 に 示した人口の推移と同様の傾向であった.

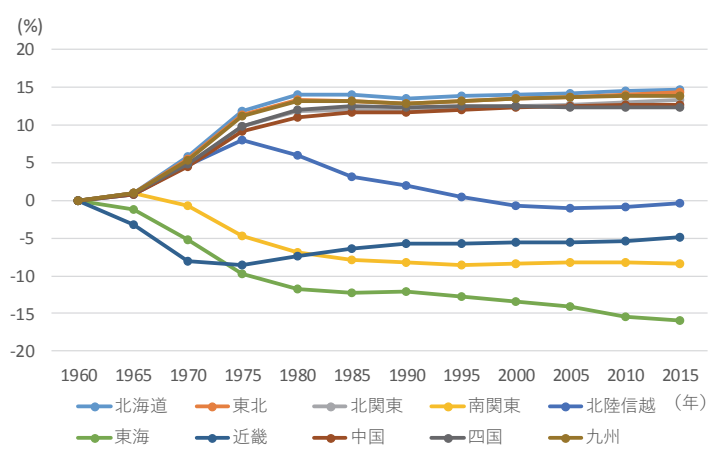

図-7 不通なしに対するシナリオ[2]の人口増減率

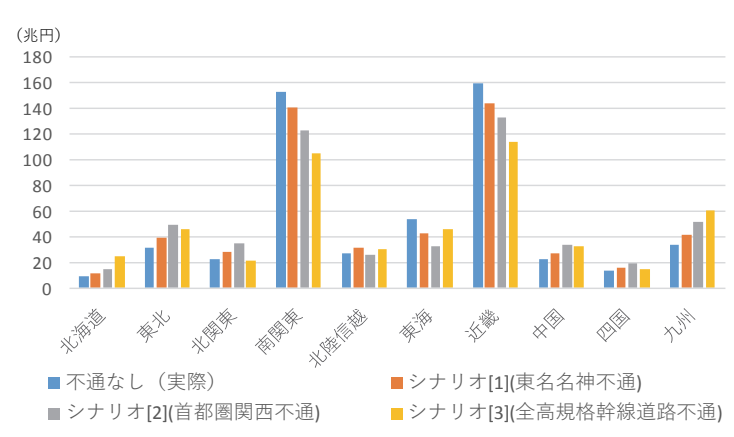

図-9 各地方の GRP（2015年）

\section{(5) 考察}

まずマクロ経済モデルの推計結果について考察を述べ る. 不通無しに対する不通シナリオの実質 GDP 減少額 は，今回不通とした路線網がもたらした実質 GDP の増 加額とも捉えられる. 寸なわち, 1985 年から 2015 年の 30 年間で実質 GDP は，東名・名神（シナリオ[1]での未 整備路線）の整備によって約 49.4 兆円，首都圈関西間の 路線（シナリオ[2]での未整備路線）の整備によって約 117.6 兆円，全ての高規格幹線道路（シナリオ[3]での未 整備路線）の整備によって約 333.5 兆円の増加をもたら したと考えられ, 高速道路網の整備が日本の経済発展に 寄与してきたことが示唆された。供用延長に対する実質 GDP 額増加への寄与は東名・名神高速道路で最も高い が，これは経済等の諸機能を担う三大都市圈，太平洋心 ルト地帯を結ぶ路線である東名高速道路, 名神高速道路 がとりわけ大きな経済的効果をもたらしてきたことを示 したものだと考えられる.

次に地域モデルの推計結果のうち, 高規格幹線道路網 の一部を未整備としたシナリオ[1]及びシナリオ[2]につ いて考察を述べる. 両シナリオでは，不通路線の沿線地 域で整備された時期に合わせ人口及び GRP が不通路線 なしの場合と比較して減少していることが確認された. これは高速道路の整備が沿線地域の人口や経済力の増加 に正の影響をもたらすことを改めて示すものだと考えら れる. 一方で両シナリオとも沿線以外の各地域では人口 
や GRP が不通無しの場合と比較して増加していること から，東名・名神高速道路や，首都圈関西を結ぶ路線網 の整備が，沿線以外の各地域から三大都市圈を中心とす る沿線地域一の人口や経済力の集中をもたらしたことが 示唆される．またシナリオ[1]からは，東名・名神高速 道路の整備による効果は，南関東に比べて東海や近畿地 域で大きいことが窺われる，この要因としては，中京圈 や関西圏の人口や経済力が，これら両都市圈以上に人口 や経済力が突出した関東圏とのアクセス性の高さによっ て，高められている可能性が考えられる.

続いて高規格幹線道路全路線を未整備としたシナリオ [3]について考察を行う。北海道と四国地域の人口や GRPの増減率に注目すると，1980年代までは両地域の増 加率は他の地域より高く，ほぼ同様の推移を辿っている. しかし 1990 年代以降は，北海道は他の地域と比べて高 いままである一方で，四国地域は増加率が減少し 2000 年代以降は北陸信越地域と同程度にまで低下している. この要因としては, 四国は 1988 年の瀬戸中央自動車道 (瀬戸大橋) の開通により本州と道路で接続され，その 後さらに 2 路線の本四連絡路線の整備が行われたのに対 し，北海道は今日に至るまで道路による接続が行われて いないことが考えられる．他の地域で交通インフラの整 備が進むことによる人口や経済力への負の影響は，当該 地域と他の地域間で高規格道路のネットワークが十分構 築されていた場合に軽減されることが示唆された。

四国以外の各地域に関して，人口や GRP が大きく減 少したのは三大都市圈を含む北関東，南関東，東海，近 畿の 4 地域であり，三大都市圈から離れた東北や九州な どの地域では他のシナリオと比べても著しく増加する結 果であった。 また三大都市圈に一部隣接する北陸信越地 域においても増加する結果となった。これは，現在の高 規格幹線道路網の整備状況が，三大都市圈を含む 4 地域 には正の影響を与える一方で，それ以外の地域には多大 な負の影響をもたらしていることを示すものであると考 えられる.

\section{5. 結論と今後の課題}

最後に, 本研究の結論を示したい. 本研究では, 三大 都市圈の人口が全国人口に占める割合等が過去数十年の 間に大きく上昇してきたこと，中でもとりわけ東京圈一 の一極化が国際的にみて稀な水準で生じている現象を指 して，「不均衡の拡大」（格差の拡大）とみなしている その上で本研究の分析結果は，アクセシビリティが地域 の人口や経済力に正の影響を及ぼすことや，高速道路が 整備されなかつた場合には不均衡の拡大が抑制されたと みられることから, 戦後の高速道路整備が首都圈をはじ
めとする大都市圈のアクセシビリティ向上に寄与してお り，そのことがこれらの地域への人口集中を促したこと を示唆していると考えられる. 本研究のモデルにおける アクセシビリティは終点の人口でウェイトを付けたもの であることから, 地方都市間のインフラ整備による所要 時間短縮効果は比較的限定されたものになる点に留意す る必要はあるが, 少なくとも戦後の高速道路整備の有無 によって不均衡拡大の度合いに変化が見られたことから， これまでの高速道路整備の方針や内容によっては不均衡 の拡大が抑制可能であったことは否定できないと考えら れる.

今後の高速道路ネットワークの整備計画においては, 過去の整備に関するこれらの知見を念頭に置き, 都市圈 と地方部の然るべきバランスを有した国土の実現に資す るかといら観点を持つことが不可欠であるだろう。従来 の整備がもたらしてきた影響の大きさを踏まえれば，人 口や経済力が大きく損なわれてきた地方部に目を向ける 適切な計画の推進によって, 我が国の不均衡の拡大は十 分抑制されらるものだと考えられる.

なお本研究の知見は, アクセシビリティの変化に伴う 各変数の変化を，これまで様々な目的に活用されてきた MasRACというシミュレーションモデルを用いて行われ た分析によって得られたものであるが，これはアクセシ ビリティの変化が及ぼす消費や供給などの様々な変数の 変化を総合的にシミュレーション分析するものである. その各方程式は，過去の計量経済データに基づいて推定 したものであり，かつ本研究の分析結果は，当該の方程 式の信頼性に依存するものである。 そして，それら方程 式のそれぞれは樋野らの研究18)に示されているように, 一定水準以上の適合度が確認されているものである. し たがって，本稿で示した分析結果は，それら方程式を推 計した時に活用した計量経済データが持つ統計的構造が, それぞれのシナリオにおいても保存されていたであろう という前提で導かれれたものである.

しかし，推定された各方程式の各係数それ自身が，各 シナリオに影響を受ける可能性を，ここで完全に排除す ることはできない，例えば現時点での本モデルは，企業 立地等の空間分布や，各地点におけるいわゆる「商圏」 の大きさ，さらには貿易状況等を変数として導入してい ないが，それらの変化が各方程式の各係数に影響を及ぼ す可能性は排除できない（すなわち，導入していない上 記の各変数と導入済みの変数との間に交互作用が存在す る可能性が残されており，そうした交互作用が存在する にも関わらずそれを考慮せずにモデルを推計し，しかも その未導入の各変数の水準がシナリオによって変化する 可能性がある場合には, シナリオ毎に各係数の水準が異 なっている可能性が生ずることになる. その検討の一つ として，アクセシビリティの変化が交通手段選択に与え 
る影響を考慮することを目的に交互作用項を導入したモ デルは本研究においても検討したが，符号条件の点から 整合性のある結果を得ることはできなかった。これは, 主効果に加えて交互作用の効果を含めたアクセシビリテ イの影響を推計するには，本研究で用いたデータに含ま れる情報が豊富でなかったことなどが主たる原因である 可能性も考えられる. この点については，さらなるデー 夕収集，整備などを行った上で，さらなる検討が必要で あると考えられる）. その可能性を想定した場合，より 多くの変数を導入する形でMasRACをさらに拡張してい くことがより得策である，地域モデルにおいても，説明 変数が道路・鉄道ACCのみとなっているが, マクロモデ ル同様に各地域の生産関数や消費関数を想定することに よって，より精緻な分析が可能になると考えられる.こ れらの点は今後の重要な課題の一つであると考えること ができる.

なお，第4章で述べた通り，マクロモデルによる実質 GDPの推計及びこの結果を用いる地域モデルの域内総生 産（GRP）の推計について，1984年以前については精度 が安定しなかったため行えておらず，この点についても 課題として残されている.

MasRAC本体以外の点でも，ACC指標を年齢別の人口 や待ち時間, 頻度などを考慮する形でさらに精緻化して いくことで，分析結果の精度向上の可能性が考えられる。 また高速道路が利用できない場合の地域間移動所要時間 の変化についても，本研究では簡易的な方法で推計した が，手段分担やOD分布の変化を考慮することで，同じ くより高い精度の計算が可能となるものと期待できる.

言うまでもなく過去に整備した高速道路は，今日に至 るまで実に多面的な影響をもたらしており，それが存在 しない場合にどういう世界が実現していたのかを推計す ることは必ずしも容易な事ではないと考えられるものの, そうした困難な推計を, 本研究においては本稿で示した 各変数を考慮し，かつ，それについて入手できたデータ を活用する範用で推計されたモデルを用いることを通し て試みた．上記のようにその推計にあたっては様々な課 題が残されてはいるものの, 現存する高速道路の価值を 推計するという困難な作業の第一歩として，その推計方 針とその初期的推計結果を提示した点に本研究の意義が あるとの期待の下，今後は上記の様な諸課題の一つ一つ に対応し，より精度の高い推計を試みることが必要であ る.

\section{参考文献}

1) 国土交通省：高規格幹線道路等の現状, http://www. mlit.go.jp/road/ir/kihon/25/3.pdf

2) 田中晧介, 中野剛志, 藤井聡 : 公共政策に関する大 手新聞社説の論調についての定量的物語分析, 土木
学会論文集 D3, Vol. 69, No. 5, pp. I_353-I_361, 2013.

3) 斎藤貢一, 小口晴香(国土交通委員会調査室): 平成 30 年度国土交通省予算及び復興庁予算のポイント, 立 法と調査, No. 397, pp. 116-131, 2018.

4) 国土交通省高速道路のあり方検討有識者委員会 : ネ ットワークのあり方を考える基本的視座, http://www. mlit.go.jp/road/ir/ir-council/hw_arikata/chu_matome2/01. pdf

5) 国土交通省道路局・同都市局：費用便益分析マニュ アル， 2018.

6) 藤井聡 : 土木計画学, pp. 147-148, 学芸出版社, 2008 .

7) 根津佳樹, 藤井聡 : 交通インフラ投資によるマクロ 経済への影響分析のためのシミュレーションモデル MasRAC の構築, 科学技術研究, Vol. 5, No. 2, pp. 185195, 2016.

8) 山内弘隆, 上田孝行, 河合穀治：一般均衡モデルに よる高速道路の費用便益分析, 高速道路と自動車, Vol. 42, No. 5, pp. 22-30, 1999.

9) 森杉壽芳, 大島伸弘：幹線交通網形成の簡便な事後 評価モデルの提案, 土木計画学研究・講演集, Vol. 7, pp. 125-132, 1985.

10) 国土交通省：インフラのストック効果とフロー効果, http://www.mlit.go.jp/sogoseisaku/region/stock/stockeffect .html

11) 中川大, 西村嘉浩, 波床正敏 : 鉄道整備が市町村人 口の変遷に及ぼしてきた影響に関する実証的研究, 土木計画学研究・論文集, Vol. 11, pp. 57-64, 1993.

12) 中里透: 社会的資本整備と経済成長一道路投資を対 象とした実証分析一, 内閣府経済社会総合研究所, 2003.

13) 門間俊幸, 佐藤啓輔, 小池淳司, 藤井聡 : 帰着便益 に着目した高速道路ネットワーク形成に関する分析 一中国地方の実証事例から一, 土木計画学研究・講 演集, Vol. 39, 2009.

14) 小池淳司, 平井健二, 佐藤啓輔 : 高速道路整備によ る地域の人口及び経済変化に関する事後分析一固定 効果モデルによるパネルデータ分析一, 土木学会論 文集 D3, Vol. 68, No. 4, pp. 388-399, 2012.

15) 要藤正任, 吉村有博 : 社会資本によるスピルオーバ 一効果と地域経済成長一市町村データを用いた高速 道路整備効果の実証分析一, KIER Discussion Paper, Vol. 1603, 2016.

16) 長澤光太郎, 小川俊幸, 由利昌平: 高速道路の整備 効果一高速道路のない日本に関する仮想的検討一, 高速道路と自動車, Vol. 37, No. 10, 1994.

17) 門間俊幸, 佐藤啓輔, 小池淳司, 中野剛志, 藤井 聡：現下の経済動向を踏まえた公共投資効果に関す る基礎的研究, 土木学会論文集 F4, Vol. 67, No. 4, pp. I_327-I_338, 2011.

18）樋野誠一, 門間俊幸, 小池淳司, 中野剛志, 藤井 聡 : インフレ・デフレ状況を内生化したケインズモデ ルによる公共投資効果の分析, 土木学会論文集 F4, Vol.68, No.4,pp. I_21-I_32, 2012.

19) 片岡将, 柳川篤志, 樋野誠一, 毛利雄一, 田中晧介, 川端佑一郎, 藤井聡: 高速道路の新規整備が国民経 済と国土構造にもたらす影響の計量分析, 交通工学 論文集特集号 A（研究論文），Vol. 5, No. 2, pp. A_275A_284, 2019.

20) 第 5 回（2010 年度）全国幹線旅客純流動調查 207 生 
活圈ゾーン, http://www.mlit.go.jp/common/000992202.

pdf

21) 張峻屹，瀬谷創，兼重仁，力石真 : 都道府県間人口

\section{AN ESTIMATION OF HISTORICAL EFFECTS OF EXPRESSWAY DEVELOPMENT ON MACROECONOMY AND POPULATION DISTRIBUTION IN JAPAN}

\section{Hirotaka UEDA, Sho KATAOKA, Atsushi YANAGAWA, Yuichiro KAWABATA and Satoshi FUJII}

In this study, we estimate the macroeconomic effect and the change in population distribution in Japan that existing highways have made by simulation model. As a result, constructing highways have contributed to improvement of GDP (From 1985 through 2015, Tomei expressway and Meishin expressway raised GDP of Japan 49.4 Trillion yen in total). On the other hands, according to analysis on production and population distribution in the country area, highway network have enhanced centralization of economic power and population in metropolitan area, especially in Tokyo and increase the disparities rural and urban areas. 